\title{
Pelaksanaan Pemberian Kredit Usaha Rakyat (KUR) pada PT Bank Rakyat Indonesia (Studi Kasus Bank BRI Merdeka Cabang Ternate)
}

\author{
Amin Muhammad \\ Fakultas Hukum Universitas Khairun. E-mail: aminmuhammadhukum@gmail.com \\ Basri Hamaya \\ Fakultas Hukum Universitas Khairun. E-mail: mbasry363@gmail.com
}

\begin{abstract}
:
Bank BRI (Bank Rakyat Indonesia) Ternate as the State Bank which works in the banking sector and also becomes one of the BUMN (State-Owned Enterprise) companies. The presence of BRI banks provides many benefits to the community, especially the people of Ternate city to be able to live better financially. The implementation of people's business credit (KUR) is carried out through several stages, namely: the loan application stage, the credit review and analysis stage (the inspection stage), the decision awarding stage, and the credit disbursement / credit agreement stage. The occurrence of bad loans is not only caused by the debtor but the mistakes made by the bank can also be one of the causes of the occurrence of bad loans, for example in analyzing credit, and not controlling the customers gradually.
\end{abstract}

Keywords: People's business credit (KUR), Bank Rakyat Indonesia

\section{PENDAHULUAN}

Sektor perbankan yang memiliki posisi strategis sebagai lembaga intermediasi dan penunjang system perbankan merupakan factor yang sangat menentukan dalam proses penyesuaian yang dimaksud. Berkaitan dengan itu, diperlukan penyempurnaan terhadap system perbankan nasional yang buka hanya mencakup upaya penyehatan bank secara individual, melainkan juga penyehatan perbankan secara menyeluruh, upaya penyehatan perbankan nasional menjadi tanggung jawab bersama antara pemerintah, bank itu sendiri dan masyarakat pengguna jasa bank. ${ }^{1}$

Dasar utama kegiatan perbankan adalah kepercayaan, baik dalam penghimpunan dana maupun penyakuran dana.oleh karena itu masyarakat menitipkan dananya di bank apabila ada unsur kepercayaan. Masyarakat percaya bahwa uangnya tidak di salah gunakan oleh bank dan di kelola dengan baik, serta pada saat yang telah di janjikan, simpanan tersebut dapat di tarik kembali oleh pihak bank. Peran perbankan dalam pembangunan ekonomi adalah mengalirkan dana bagi kegiatan ekonomi yaitu salah satunya dalam bentuk perkreditan bagi masyarakat perseorangan atau badan usaha. Kredit tersebut mempunyai suatu kedudukan yang strategis dimana sebagai salah satu sumber uang yang diperlukan dalam membiayai kegiatan usaha yang dapat dititikberatkan sebagai salah satu kunci kehidupan bagi setiap manusia. Fasilitas kredit yang diberikan oleh bank merupakan asset terbesar bagi bank Dalam hal kegiatan bank memberikan fasilitas kredit, resiko kerugian sebagian besar bersumber pada kegiatan tersebut,

\footnotetext{
${ }^{1}$ H. Boedi Abdullah 9 Oktober 2018
} 
sehingga bila tidak dikelola dengan baik dan disertai pengawasan yang memadai akan mengancam kelangsungan hidup bank tersebut ${ }^{2}$.

Usaha mikro, kecil dan menengah juga memegang peran penting dalam pembangunan ekonomi karena tingkat penyerapan tenaga kerjanya yan relative tinggi dan kebutuhan moda linvestasinya yang kecil. Hal ini membuat UMKM ( Usaha Mikro, Kecil dan Menengah) tidak rentan terhadap berbagai perubahan eksternal sehingga pengembangan pada sector UMKM dapat menunjang diversifikasi ekonomi dan percepatan perubahan structural yang merupakan prasyarat bagi pembangunan ekonomi jangka panjang yang stabil dan berkesinambungan. Pemerintah Republik Indonesia mengeluarkan Inpres Nomor 6 tanggal 8 Juni 2007 tentang Kebijakan Percepatan Pengembangan Sektor Riil dan Pemberdayaan UMKM yang diikuti dengan nota kesepahaman bersama antara Departemen Teknis, Perbankan, dan Perusahaan Penjaminan Kredit/ Pembiayaan kepada UMKM. Akhirnya pada tanggal 5 November 2007, Presiden R.I Susilo Bambang Yudoyono meresmikan kredit bagi UMKM dengan pola penjaminan dengan nama Kredit Usaha Rakyat dan didukung oleh Inpres Nomor 5 Tahun 2008 tentang Fokus Program Ekonomi 2008-2009 untuk menjamin implementasi atau percepatan pelaksanaan kredit usaha rakyat ini. ${ }^{3}$

Tahap awal program, Kredit Usaha Rakyat ini disediakan hanya terbatas oleh bank- bank yang ditunjuk oleh pemerintah saja, yaitu: Bank Rakyat Indonesia (BRI), Bank Negara Indonesia (BNI), Bank Mandiri, Bank Syariah Mandiri, Bank Tabungan Negara dan Bank Bukopin. Penyaluran pola penjaminan difokuskan pada lima sector usaha, yaitu pertanian, perikanan dan kelautan, koperasi, kehutanan, serta perindustrian dan perdagangan. Kredit Usaha Rakyat ini ditujukan untuk membantu ekonomi usaha rakyat kecil dengan cara member pinjaman untuk usaha yang didirikannya. Diajukannya permohonan peminjaman kredit tersebut, tentu saja harus mengikuti berbagai prosedur yang ditetapkan oleh bank yang bersangkutan. Selain itu, pemohon harus mengetahui hak dan kewajiban yang akan timbul dari masing-masing pihak yaitu debitur dan kreditur dengan adanya perjanjian Kredit Usaha Rakyat, mengingat segala sesuatu dapat saja timbul menjadi suatu permasalahan apabila tidak ada pengetahuan yang cukup tentang Kredit Usaha Rakyat.

Bank BRI (Bank Rakyat Indonesia) Ternate sebagai Bank Negara yang bergreak di bidang perbankan dan juga menjadi salah satu perusahan BUMN (Badan Usaha Milik Negara). Hadirnya bank BRI memberikan banyak manfaat kepada masyarakat, khusunya masyarakat kota Ternate untuk bisa hidup menjadi lebih baik dari sisi finansial. ${ }^{4}$ Bank BRI mampu menyalurkan dan melakukan segala jenis kegiatan perbakan terbaik dengan mengutamakan pelayananyang di berikan kepada badan usaha mikro, menengah, dan kecil guna meningkatkan perekonomian masyarakat kota Ternate. Bank BRI mampu memberikan KUR kepada nasabah apabila nasabah itu, telah melakukan usaha secara aktif minimal enam bulan, mempunyai produktif dan layak. Bank BRI juga punya cara penyelesaian jika KUR tersebut mengalami kendala atau macet, ada dua pilhan yang di berikan bank BRI yaitu penyelesaian kredit macet secara damai antara kedua pihak, bank dan nasabah tanpa melalui pengadilan (non-litigasi) dan penyelesaian melalui pengadilan (litigasi). Berdasarkan uraian di atas, penulis tertarik untuk menulis artikel dengan judul "Pelaksanaan Pemberian Kredit Usaha Rakyat (KUR) Pada PT Bank Rakyat Indonesia Merdeka Ternate”.

\section{KAJIAN KEPUSTAKAAN}

\section{A. Bank}

Bank berasal dari kata Banco, yang berarti bangku. Bangku atau pelaku bank adalah bankir yang melayani kegiatan operasional bank kepada para nasabah. Bank merupakan industri jasa

\footnotetext{
${ }^{2}$ http://serlania.blogspot.co.id 10 Oktober 2018

${ }^{3} \mathrm{https}: / /$ www.scribd.com Perbankan Indonesia 10 Oktober 2018

${ }^{4}$ https://bank-rakyat-indonesia
} 
yang memberikan pelayanan jasa kepada masyarakat dan merupakan badan atau lembagakeuangan yang tugas utamanya menghimpun uang dari pihak ketiga sebagai perantara untuk menyalrkan permintaan dan penawaran kredit pada waktu yang di tentukan. ${ }^{5}$

Beberapa ahli perbankan mendefenisikan bank sebagai berikut :

1) Menurut G.M. Verry Stuart, bank adalah badan yang usaha utamanya menciptakan kredit yang bertujuan memuaskan kebutuhan kredit, baik dengan alat pembayaran sendiri atau dengan uang yang di perolehnya dari orang lain maupun dengan jalan mengedarkan alat-alat penukar baru berupa uang giral.

2) Bank adalah saluran untuk menginvestasikan tabungan secara aman dan dengan tingkat bung yang menarik.

3) Menurut Malayu S.P. Hasibuan, bank adalah lembaga keuangan, pencipta uang, pengumpul dana dan penyaluran kredit, pelaksanaan lalu lintas pembayaran, stabilisator moneter, serta dinamisator pertumbuhan ekonomi.

4) Bank adalah pencipta uang, yaitu menciptakan uang giral dan mengedarkan uang kuartal.

5) Menurut Undang-Undang RI Nomor 10 tahun 1998 tanggal 10 November 1998 tentang perbankan, yang dimaksud dengan bank adalah badan usaha yang menghimpun dana dari masyarakat dalam bentuk simpanan dan menyalurkan kepada masyarakat dalam bentuk kredit dan bentuk-bentuk lainnya dalam rangka meningkatkan taraf hidup masyarakat. ${ }^{6}$

Menurut kegiatan atau fungsinya, ada tiga macam bank, yaitu Bank Sentral, Bank Umum dan BPR (Bank Perkreditan Rakyat).

1) Bank Sentral

Bank Sentraladalah bank yang bertanggung jawab menjaga kestabilan nilai rupiah dan mengatur serta mengawasi kegiatan lembaga-lembaga keuangan. Sesuai dengan namanya (Bank Sentral atau Bank Pusat) maka hanya ada satu bank sentral di suatu negara. Di Indonesia, kedudukan bank sentral dipegang oleh Bank Indonesia. Sedang di Amerika, bank sentral dipegang oleh Federal Reserve System di Inggris dipegang oleh Bank of England.

Menurut Undang-Undang No. 23 Tahun 1999 tentang Bank Indonesia, Bank Indonesia merupakan lembaga negara yang independen, bebas dari campur tangan pemerintah atau pihak-pihak lainnya, kecuali untuk hal-hal yang secara tegas diatur dalam undang-undang tersebut. Menurut undangundang itu juga, tujuan didirikannya Bank Indonesia adalah untuk mencapai kestabilan nilai rupiah. Yang dimaksud kestabilan nilai rupiah adalah kestabilan nilai rupiah terhadap barang dan jasa serta terhadap mata uang negara lain. Kestabilan nilai rupiah terhadap barang dan jasa dapat dilihat dari perkembangan laju inflasi. Adapun kestabilan nilai rupiah terhadap mata uang negara lain, dapat dilihat dari perkembangan nilai tukar rupiah.

2) Bank Umum

Bank umum adalah bank yang melaksanakan kegiatan menghimpun dana dari masyarakat, memberikan pinjaman kepada masyarakat, serta memberikan jasa pelayanan di bidang keuangan. Dikatakan umum karena memberikan jasa kepada masyarakat umum, dan dapat beroperasi di seluruh wilayah.

3) Bank Perkreditan Rakyat (BPR)

BPR adalah bank yang melaksanakan kegiatan menerima simpanan dari masyarakat hanya dalam bentuk deposito berjangka, tabungan atau bentuk lainnya serta

\footnotetext{
${ }^{5}$ H. Dadang Husen Sobana Hukum Perbankan Indonesia. 12 Okotober 2018

${ }^{6}$ Undang-Undang Dasar Nomor 10 tahun 1998 tentang Perbankan. 12 Oktober 2018

${ }^{7}$ Ibid hal 51
} 
memberikan pinjaman kepada masyarakat. Dengan demikian, usaha yang bisa dilakukan BPR lebih sedikit atau lebih sempit dibandingkan bank umum.Kredit

Sutan Remy Sjahde ini menyatakan bahwa sifatnya yang konsensual dari suatu perjanjian kredit bank itulah yang merupakan cirri pertama yang membedakan dari perjanjian peminjaman uang yang bersifat riil. Perjanjian kredit adalah perjanjian loan of money menurut hokum Inggris yang dapat bersifatriil maupun konsensual tetapibukan perjanjian peminjaman uang menurut hokum Indonesia yang bersifat riil. ${ }^{8}$

Perjanjian kredit yang jelas-jelas mencantumkan syarat tangguh tidak dapatdibantah lagi bahwa perjanjian kredit merupakan perjanjian yang konsensuil sifatnya, setelah perjanjian kredit ditandatangani oleh bank maupun oleh nasabah, nasabah belum berhak menggunakan atau melakukan penarikan kredit atau sebaliknya, setelah ditandatanganinya kredit oleh kedua belah pihak, belumlah menimbulkan kewajiban bagi bank untuk menyediakan kredit, masih tergantung kepadatelah terpenuhinya seluruh syarat yang ditentukan didalam perjanjian kredit.

Undang-Undang Perbankan yang telah diubah tidak menentukan bentuk perjanjian kredit, berarti bahwa pemberian kredit bank dapat dilakukan secara tertulis maupun lisan. Secara umum dalam praktek perbankan, perjanjian kredit dituangkan dalam bentuk tertulis dan dalam perjanjian baku. Perjanjian kredit banknya bisa dibuat di bawah tangan dan bisa secara notarial.

Perjanjian kredit mempunyai beberapa fungsi diantaranya:

1) Perjanjian kredit berfungsi sebagai perjanjian pokok,artinya perjanjian kredit merupakan sesuatu yang menentukan batal atau tidaknya perjanjian lain yang mengikutinya.

2) Perjanjian kredit berfungsi sebagai alat bukti mengenai batasan-batasan hak dan kewajiban diantara debitor dan kreditor.

3) Perjanjian kredit berfungsi sebagai alat monitoring kredit.

Perjanjian kredit merupakan perjanjian baku dimanaisi atau klausula perjanjian kredit tersebut telah dibakukan dan dituangkan dalam bentuk formulir (blanko), tetapi tidak terikat dalam suatu bentuk tertentu. Keabsahan perjanjian kredit terletak pada penerimaan masyarakat dan lalulintas bisnis untuk memperlancar arus lalulintas perdagangan dan bisnis. Perjanjian baku pada umumnya mengandung klausula yang tidaksetara antara pihak yang mempersiapkan dan pihak lainnya.

Setiap pemberian kredit harus dituangkan dalam perjanjian kredit secara tertulis. Bentuk dan formatnya diserahkan oleh Bank Indonesia kepada masing-masing bank untuk menetapkannya, namun sekurang-kurangnya harus memperhatikan hal-hal sebagai berikut:

1) Memenuhi keabsahan dan persyaratan hokum yang dapat melindungi kepentingan bank.

2) Memuat jumlah jangka waktu, tata cara pembayaran kembali kredit serta persyaratanpersyaratan kredit lainnya sebagaimana ditetapkan dalam keputusan persetujuan kredit dimaksud.

Susunan sebuah perjanjian kredit bank pada umumnya meliputi :

1) Judul

Dunia perbankan masih belum terdapat kesepakatan tentang judul atau penamaan perjanjian kredit bank ini.

2) Komparisi

\footnotetext{
${ }^{8}$ https://id.wikipedia.org/wiki/Kredit_Usaha_Rakyat 15 Oktober 2018
} 
Komparisi menjelaskan sejelasnya tentang identitas, dasar hukum, dan kedudukan subjek hukum perjanjian kredit bank. Sebuah perjanjian kredit bank akan dianggap sah bila ditandatangani oleh subjek hokum yang berwenang untuk melakukan perbuatan hokum yang demikian itu.

3) Substansi

Sebuah perjanjian kredit bank berisikan klausula-klausula yang merupakan ketentuan dan syarat pemberian kredit seperti, maksimal kredit, bunga dan denda, jangka waktu kredit, cara pembayaran kembali dan lain-lain.

\section{B. Jaminan}

Pasal 1131 KUHPerdata menjelaskan bahwa:"segalakebendaan si berutang, baik yang bergerak maupun yang tak bergerak,baik yang sudah ada maupun yang baru akan ada dikemudian hari, menjadi tanggungan untuk segala perikatan perseorangan". Penjelasan diatas menyiratkan bahwa jaminan harus ada dalam hal suatu perikatan. Istilah jaminan dalam perspektif hukum perbankan dibedakan dengan istilah agunan. Arti jaminan yaitu keyakinan atas itikad dan kemampuan serta kesanggupan nasabah debitur untuk melunasi utangnya atau mengembalikan pembiayaan dimaksud sesuaidengan yang diperjanjikan. ${ }^{9}$

Istilah agunan sesuai Pasal 1 angka 23 Undang-Undang Nomor 10 tang Perubahan Atas Undang-Undang Nomor 7 Tahun 1992 tentang Perbankan yaitu jaminan tambahan yang diserahkan nasabah debitur kepada bank dalam rangka pemberian fasilitas kreditatau pembiayaan berdasarkan prinsip syariah.

Jaminan Kredit adalah segala sesuatu yang mempunyai nilai mudah untuk dituangkan yang diikat dengan janji sebagai jaminan untuk pembayaran dari utang debitur berdasarkan perjanjian kredit yang dibuat kreditur dan debitur, jaminan ideal yang secara maksimal dapat menjamin bahwa kreditor dapat menerima kembali uang yang dipinjamkan harus memenuhi semua syarat sebagai berikut:

1) Tidak menyusahkan debitur dalam melakukan usahanya, sehingga memungkinkan debitur membayar kembali utangnya.

2) Mudah diidentifikasi.

3) Setiap waktu tersedia untukdieksekusi.

4) Nilai yang tidakmudahmerosot.

Fungsi jaminan kredit baik ditinjau dari sisi bank maupun dari sisi debitur dapat dikemukakan sebagai berikut:

1) Jaminan Kredit sebagai Pengaman Pelunasan Kredit

Keterkaitan jaminan kredit dengan pengamanan kredit dapat disimpulkan dari ketentuan Pasal 1131 KUH Perdata sehingga merupakan upaya lain atau alternatif yang dapat digunakan bank untuk memperoleh perlunasan kredit pada waktu debituringkar janji kepada bank.

2) Jaminan Kredit sebagai Pendorong Motivasi Debitur

Pengikatan jaminan kredit yang berupa harta milik debitur yang dilakukan oleh pihak bank, tentunya debitur yang bersangkutan takut akan kehilangan hartanya tersebut. Hal ini akan mendorong debitur berupaya untuk melunasi kreditnya kepada bank agar hartanya yang dijadikan jaminan kredit tersebut tidak kehilangan karena harus dicairkan oleh bank.

3) Fungsi yang Terkait dengan Pelaksanaan Ketentuan Perbankan

\footnotetext{
${ }^{9}$ Drs. Muhammad Djumahana, S.H Hukum Perbankan di Indonesia 15 Otober 2018
} 
Keterkaitan jaminan kredit dengan ketentuan perbankan yang dikeluarkan oleh Bank Indonesia, misalnya dapat diperhatikan dari ketentuan-ketentuan yang mengatur tentang penilaian agunan sebagai factor pengurang dalam perhitungan PPA, persyaratan agunan untuk restrukturisasi kredit yang dilakukan dengan cara pemberian tambahan fasilitas kredit dalam rangka manajemen risiko kredit dan sebagainya.

\section{Kredit Usaha Rakyat}

Peraturan Menteri Keuangan Nomor135/PMK.05/2008 tentang Fasilitas Penjaminan Kredit Usaha Rakyat, pengertian KUR adalah kredit atau pembiayaan kepada UMKM-K (Usaha Mikro, Kecil, Menengah-Koperasi) dalam bentuk pemberian modal kerja dan investasi yang didukung fasilitas penjaminan untuk usaha produktif.

Kredit Usaha Rakyat (KUR) adalah kredit atau pembiayaan yang diberikan oleh perbankan kepada UMKM-K yang feasible tapibelumbankable. Maksudnya adalah usaha tersebut memiliki prospek bisnis yang baik dan memiliki kemampuan untuk mengembalikan. Usaha mikro, kecil, menengah dan koperasi (UMKM-K) yang diharapkan dapat mengakses KUR adalah yang bergerakdi sektorusahaprodiktif antara lain: pertanian, perikanan, dan kelautan, perindustrian, kehutanan, danjasa keuangan simpan pinjam.

Peluncuran Kredit Usaha Rakyat(KUR) merupakan tindak lanjut dari ditandatanganinya nota kesepahaman bersama (MoU) pada tanggal 9 Oktober 2007 tentang Penjaminan Kredit/Pembiayaan kepada UMKM-Kantara Pemerintah (Menteri Negara Koperasi dan UKM, Menteri Keuangan, Menteri Pertanian, Menteri Perindustrian, Menteri Kehutanan, Menteri Kelautan dan Perikanan, Perusahaan Penjamin (Perum Sarana Pengembangan Usaha dan PT. Asuransi Kredit Indonesia) dan Perbankan (BRI, Bank Mandiri,Bank Bukopin, BNI, BTN,dan Bank Syariah Mandiri). KUR ini didukung oleh Kementrian Negara BUMN, Kementerian Koordinasi Bidang Perekonomian, serta Bank Indonesia.

Landasan operasional KUR adalah Instruksi Presiden Nomor 5 tahun 2008 tentang Fokus Program Ekonomi Tahun 2008-2009 untuk menjamin implementasi atau percepatan pelaksanaan KUR dan Nota Kesepahaman Bersama (MoU) antara Departeman Teknis, Perbankan dan Perusahaan Penjaminan yang ditandatangani padatanggal 9 Oktober $2007^{10}$.

Menurut Marguiret Robinson dalam Wiloejo WirjoWijono, pinjaman dalam bentuk mikro kredit merupakan salah satu upaya yang ampuh dalam menangani kemiskinan. Hal tersebut didasarkan bahwa pada masyarakat miskin sebenarnya terdapat perbedaan klasifikasi diantara mereka, yang mencakup: masyarakat yang sangat miskin(the extremepoor) yakni mereka yang tidak berpenghasilan dan tidak memiliki kegiatan produktif, kedua masyarakat yang dikategorikan miskin namun memiliki kegiatan ekonomi (economicallyactive working poor),dan yang ketiga yaitu masyarakat yang berpenghasilan rendah (lower income).

Keuangan mikro adalah penyaluran jasakeuangan kepada rakyat kecil, lemah/miskin,danparawirausaha. Sejak tahun 1970, microfinance mengalami peningkatan dalamperkembangannya,dandalamprakteknya merupakan penggabungan konsep pengembangan social dan ekonomi, juga merupakan atau sebagai prinsip yang mendasari promosi dan keuangan pasar/penjualan.kombinasi ini telah membawadampak jumlah pertumbuhan lembaga keuangan mikroyang berkelanjutan dalam pengembangan dunia.

UMKM dan Koperasi yang membutuhkan Kreditdapat menghubungi Kantor Cabang Pembantu Bank Pelaksterdekat. Memenuhi persyaratan dokumentasi sesuai dengan yang ditetapkan Bank Pelaksana. Mengajukan surat permohonan kredit/pembiayaan kemudian Bank Pelaksana akan melakukan penilaian kelayakan (Bank Pelaksana berwenang memberikan persetujuan atau menolak permohonan kredit).

${ }^{10}$ kur.ekon.go.id/landasan-hukum 24 Oktober 2018 


\section{Bank Rakyat Indonesia}

Bank Rakyat Indonesia (BRI) adalah salah satu bank milik pemerintah yang terbesar di Indonesia. Pada awalnya Bank Rakyat Indonesia (BRI) didirikan di Purwokerto, Jawa Tengah oleh Raden Bei Aria Wirjaatmadja dengan nama De Poerwokertosche Hulp en Spaarbank der Inlandsche Hoofden atau "Bank Bantuan dan Simpanan Milik Kaum Priyayi Purwokerto", suatu lembaga keuangan yang melayani orang-orang berkebangsaan Indonesia (pribumi). Lembaga tersebut berdiri tanggal 16 Desember 1895, yang kemudian dijadikan sebagai hari kelahiran BRI.

Pada periode setelah kemerdekaan RI, berdasarkan Peraturan Pemerintah No. 1 tahun 1946 Pasal 1 disebutkan bahwa BRI adalah sebagai Bank Pemerintah pertama di Republik Indonesia. Dalam masa perang mempertahankan kemerdekaan pada tahun 1948, kegiatan BRI sempat terhenti untuk sementara waktu dan baru mulai aktif kembali setelah perjanjian Renville pada tahun 1949 dengan berubah nama menjadi Bank Rakyat Indonesia Serikat. Pada waktu itu melalui PERPU No. 41 tahun 1960 dibentuklah Bank Koperasi Tani dan Nelayan (BKTN) yang merupakan peleburan dari BRI, Bank Tani Nelayan dan Nederlandsche Maatschappij (NHM). Kemudian berdasarkan Penetapan Presiden (Penpres) No. 9 tahun 1965, BKTN diintegrasikan ke dalam Bank Indonesia dengan nama Bank Indonesia Urusan Koperasi Tani dan Nelayan.

Setelah berjalan selama satu bulan, keluar Penpres No. 17 tahun 1965 tentang pembentukan bank tunggal dengan nama Bank Negara Indonesia. Dalam ketentuan baru itu, Bank Indonesia Urusan Koperasi, Tani dan Nelayan (eks BKTN) diintegrasikan dengan nama Bank Negara Indonesia unit II bidang Rural, sedangkan NHM menjadi Bank Negara Indonesia unit II bidang Ekspor Impor (Exim).

Berdasarkan Undang-Undang No. 14 tahun 1967 tentang Undang-undang Pokok Perbankan dan Undang-undang No. 13 tahun 1968 tentang Undang-undang Bank Sentral, yang intinya mengembalikan fungsi Bank Indonesia sebagai Bank Sentral dan Bank Negara Indonesia Unit II Bidang Rular dan Ekspor Impor dipisahkan masing-masing menjadi dua Bank yaitu Bank Rakyat Indonesia dan Bank Ekspor Impor Indonesia. Selanjutnya berdasarkan Undangundang No. 21 tahun 1968 menetapkan kembali tugas-tugas pokok BRI sebagai bank umum. Bank BRI merupakan sebuah perusahaan yang bergerak dibidang perbankan dan juga menjadi salah satu perusahaan BUMN. Hadirnya bank BRI memberikan banyak manfaat kepada masyarakat untuk bisa hidup menjadi lebih baik dari sisi finansial.

\section{METODE PENELITIAN}

Mengacu pada perumusan masalah, maka penelitian ini termasuk dalam jenis penelitian hukum yuridis empiris. Dalam hal ini, peneliti berusaha memberikan dan menguraikan tentang pelaksanaan prosedur pemberian Kredit Usaha Rakyat (KUR) beserta permasalahan yang ditimbulkan karenanya. Lokasi penelitian dilakukan di PT Bank Rakyat Indonesia KCP Unit Merdeka Kompleks Bisnis Ruko Jatiland Ternate, Kota Ternate Maluku Utara.

Jenis data yang digunakan penulis dalam penelitian ini adalah

1. Data Primer

Data primer adalah data atau fakta atau keterangan yang diperoleh secara langsung dari sumber pertama atau melalui penelitian dilapangan yaitu berupa hasil wawancara dengan pihak yang berkompeten di PT. Bank Rakyat Indonesia Unit Merdeka Ternate, yaitu Kepala Unit PT. Bank Rakyat Indonesia Unit Merdekadan Mantri/AO PT. Bank Rakyat Indonesia Unit Merdeka Ternate.

2. Data Sekunder

Data sekunder adalah data atau fakta atau keterangan yang digunakan oleh seseorang yang secara tidak langsung dari lapangan, antara lain mencakup lembar permohonan 
kredit usaha rakyat di PT. Bank Rakyat Indonesia Unit Merdeka Cabang Ternate, literatur, catatan, karya ilmiah, laporan penelitian, dan sumber lain yang relevan dan berkaitan dengan masalah yang diteliti.

Sumber Data Penelitian yang digunakan adalah :

1. Sumber Data Primer

Sumber data primer merupakan sumber data yang berupa keterangan-keterangan dri pihak-pihak yang terkait secara langsung dengan permasalahan yang diteliti yaitu hasil wawancara dengan pejabat Bank Rakyat Indonesia serta nasabah kredit usaha rakyat.

2. Sumber Data Sekunder

Sumber data sekunder adalah sumber data yang secara tidak langsung memberikan keterangan yang bersifat mendukung sumber data primer. Terdiri atas lembar permohonan kredit usaha rakyat.

Teknik pengumpulan data yang digunakan penulis dalam penelitian ini adalah:

1. Wawancara

Wawancara merupakan cara memperoleh data dengan jalan melakukan Tanya jawab secara mendalam dengan sumber data primer, yaitu pihak-pihak yang berkompeten di PT Bank Rakyat Indonesia Unit Merdeka Cabang Ternate dan para debitur.

2. Studi Kepustakaan

Suatu teknik pengumpulan data dengan cara mengumpulkan dokumen- dokumen, buku-buku, dan bahan pustakalainnya yang berkaitan dengan pembahasan penelitian. Dalam hal ini penulis mengumpulkan data-data dengan mempelajari:

a. Dokumen-dokumen atau berkas-berkas lainnya yang diperoleh dari PT Bank Rakyat Indonesia Unit Merdeka Ternate.

b. Buku-buku serta bahan pustaka lainnya yang berkaitan dengan pokok-pokok bahasan penelitian.

\section{PEMBAHASAN}

\section{A. Pelaksanaan Pemberian Kredit Usaha Rakyat Pada Bank BRI Merdeka Ternate}

Berdasarkan hasil penelitian penulis di kantor BRI Unit Merdeka Cabang Ternate yang dilakukan pada tanggal 17-19 Desember 2018 dan pada tanggal 27-28 Desember 2018 serta hasil wawancara yang dilakukan penulis dengan Kepala Unit, Mantri (AccountOfficer/AO) maka penulis dapat mengemukakan bahwa proses pemberian KUR dilakukan secara bertahap yaitu sebagai berikut:

\section{Tahap PermohonanKredit}

Calon debitur mengajukan permohonan kredit usaha rakyat (KUR) secara tertulis kepada pihak BRI Unit Merdeka Ternate. Calon debitur KUR datang kekantor BRI Unit Merdeka Ternate, kemudian dengan dibantu oleh Customer Service, calon debitur KUR mengisi formulir pendaftaran atau formulir pengajuan permohonan KUR yang sudah disediakan pihak bank, kemudian ditanda tangani oleh pemohon. hasil wawancara dengan Ibu Anti Ismail selaku Kepala Unit BRI Unit Medeka Cabang Ternate pada tanggal 17 Desember 2018 pukul 16.00WIT ${ }^{11}$.

Calon debitur kredit usaha rakyat diharuskan memenuhi persyaratan yang telah ditetapkan dalam hal pengajuan permohonan kredit usaha rakyat. Kredit usaha rakyat diperkenalkan

${ }^{11}$ Wawancara dengan Kepala Unit BANK BRI Merdeka 17 Desember 2018 pukul 16.00 WIT 
sebagai kredit yang mudah didapat, maka syarat- syarat yang ditetapkan pun sangat sederhana. Syarat-syarat yang perlu disertakan adalah bukti identitas diri berupa foto kopi Kartu Tanda Penduduk (KTP), foto kopi Kartu Keluarga (KK), dan Surat Keterangan Usaha.

Bank perlu memperhatikan prinsip-prinsip dalam menilai suatu permohonan kredit yaitu sebagai berikut

1) Bank hanya memberikan kredit apabila permohonan kredit diajukan secara tertulis. Hal ini berlaku baik untuk kredit baru, perpanjangan jangka waktu, tambahan kredit,maupun permohonan perubahan persyaratan kredit,

2) Permohonan kredit harus memuat informasi yang lengkap dan memenuhi persyaratan sesuai denganketentuan yang ditetapkan oleh

3) Bankharus memastikan kebenaran data informasi yang disampaikan dalam permohonan kredit.

2. Tahap AnalisisKredit/Tahap Pemeriksaan

Berdasarkan arahan Bank Indonesia sebagaimana termuat dalam SK Direksi Bank Indonesia No.27/162/KEP/DIR tanggal 31 Maret 1995, setiap permohonan kredit yang telah memenuhi syarat harus dianalisis secara tertulis dengan pinsip sebagai berikut:

1) Bentuk, format, dan kedalaman analisis kredit ditetapkan oleh bank yang disesuaikan dengan jumlah dan jenis kredit.

Berdasarkan semata-mata atas pertimbangan permohonan untuk satu transaksi atau satu rekening kredit dari pemohon, namun harus didasarkan atas dasar penilaian seluruh kredit dari pemohon kredit yang telah diberikan dan atau akan diberikan secara bersama-sama oleh bank,

2) Analisis kredit harus dibuat secara lengkap, akurat, dan objektif yang sekurangkurangnya meliputi ;

1) Menggambarkan semua informasi yang berkaitan dengan usaha dan data pemohon termasuk hasil penelitian pada daftar kredit macet,

2) Penilaian kelayakan jumlah permohonan kredit dengan kegiatan usaha yang akan dibiayai dengan sasaran menghindari kemungkinan terjadinya praktek yang dapat merugikan bank.

3) Menyajikan penilaian yang objektif dan tidak dipengaruhi oleh pihak- pihak yang berkepentingan dengan permohonan kredit.

4) Analisa kredit sekurang-kurangnya harus mencakup penilaian tentang prinsip 5C dan penilaian terhadap sumber pelunasan kredit yang dititik beratkan pada hasil usaha yang dilakukan pemohon serta menyediakan aspek yuridis perkreditan dengan tujuan untuk melindungi bank atas resiko yang mungkin timbul.

5) Dalam penilaian kredit sindikasi harus dinilai pula bank yang bertindak sebagai bank induk.

Bagaimanapun arahan diatas, tetap terbuka peluang bagi bank-bank untuk mengatur kebijakan kreditnya sesuai dengan kondisi dan kebutuhan bank itu sendiri. BRI Unit Merdeka Cabang Ternate dalam melakukan analisis kredit pun mempunyai kebijakan sendiri yang tentunya tetap berpedoman pada arahan Bank Indonesia. Laporan Keuangan calon debitur merupakan salah satu data pokok mutlak dalam hal analisis.

Pada tahap pemeriksaan, setelah syarat-syarat dilengkapi, pihak BRI Unit Merdeka dalam hal ini Mantri (account officer) akan melakukan checking serta peninjauan langsung ke lapangan tentang layak atau tidaknya calon debitur kredit usaha rakyat diberikan pinjaman dengan menanyakan hal-hal yang berkaitan dengan permohonan KUR tersebut antara lain :

1) Mencocokan fotokopi bukti diri/identitas lain sesuai dengan aslinya. 
2) Menanyakan hal-hal yang berhubungan dengan usaha calon debitur kredit usaha rakyat. Misalnya: tentang modal, tentang pinjaman padapihak lain. Tujuannya adalah untuk menganalisis apakah calon debitur mampu mengembalikan pinjaman atau tidak.

3) Menanyakan tentang keuntungan dari usaha calon debitur kredit usaha rakyat dengan tujuan untuk mengetahui kemampuan membayar pinjaman. Hasil wawancara dengan iksan selaku Mantri/Account Officer BRI Unit Merdeka Cabang Ternate pada tanggal 27 Desember 2018 pukul 16.00 WIT. ${ }^{12}$

3. Tahap Pemberian PutusanKredit

Tahap ini, calon debitur akan memperoleh keputusan kredit yang berisi persetujuan akana danya pemberian kredit usaha rakyat sesuai permohonan yang diajukannya. Keputusan persetujuan permohonan kredit berupa mengabulkan sebagian atau seluruh permohonan kredit dari calon debitur. Pihak BRI Unit Merdeka akan memberitahukan kepada calon debitur untuk mengkonfirmasi kembali beberapa hari menurut hari yang telah ditentukan oleh pihak bank setelah pengajuan permohonan kredit. Biasanya pemberian putusan dilakukan 3-5 hari setelah pendaftaran permohonan kredit usaha rakyat. Wawancara tanggal 27 Desember 2018 pukul 09.00WIT, dengan Iksan selaku Mantri (AO) BRI Merdeka Cabang Ternate

Pada BRI Unit Merdeka Ternate, sebelum pemberian putusan kredit, Kepala Unit BRI Unit Merdeka wajib meneliti danmemastikan bahwa dokumen-dokumen yang berkaitan atau yang mendukung pemberian keputusan kreditmasih berlaku lengkap,sah,dan berkekuatan hukum.

Setiap pejabat yang terlibat dalam kebijakan persetujuan kredit harus mampu memastikan halhal berikut:

Setiap kredit yang diberikan telah sesuai dengan prinsip perkreditan yang sehat dan ketentuan perbankan lainnya,

1. Pemberian kredit telah sesuai dan didasarkan pada analisis kredit yang jujur, objektif, cermat, dan seksama (menggunakann 5C' sprinciplesi) serta independent,

2. Adanya keyakinan bahwa kredit akan mampu dilunasi oleh debitur.

Kebijakan dari BRI Unit Merdeka Cabang Ternate, yang dapat diberikan kredit usaha rakyat ini adalah debitur yang memiliki usaha mikro, kecil, menengah (UMKM). BRI Unit Merdeka tidak turut serta menyertakan koperasi, karena sampai saat ini BRI Unit Kuwarasan Gombong belum memberlakukan Link age Program dimana kredit terhadap UMKM dapat disalurkan melalui koperasi.

4. Tahap Pencairan Kredit.

Setiap proses pencairan kredit (disbursement) harus terjamin asas aman, terarah, dan produktif dan dilaksanakan apabila syarat yang ditetapkan dalam perjanjian kredit telah dipenuhi oleh pemohon kredit. Setelah semua persyaratan terpenuhi dan pemberian kredit diikat oleh perjanjian kredit maka debitur dapat mengambil dana pinjaman yang telah dimohonkan kepada bagian teller BRI Unit Merdeka Ternate.

Pencairan meliputi beberapa tahap yaitu tahap persiapan pencairan, penandatangan perjanjian pencairan kredit, fiat bayar dan pembayaran pencairan kredit. Hasil wawancara dengan Iksan selaku mantra / AO pada BRI Unit Merdeka Cabang Ternate pada tanggal 29 Desember 2018 pukul 09.00WIT. ${ }^{13}$

Adapun penjelasan mengenai langkah-langkah pada tahap akad kredit adalah sebagai berikut:

1. Persiapan Pencairan

Setelah Surat Keterangan Permohonan Pinjam (SKPP) diputus, Costumer Services mencatatnya pada register dan segera mempersiapkan pencairan sebagai berikut:

1) Memberitahukan pada calon debitur bahwa permohonan KURnya telah mendapat persetujuan atau putusandan kepastian tanggal pencairannya.

\footnotetext{
${ }^{12}$ Wawancara dngan Iksan mantra BRI 27 Desember 2018 pukul 09.00 WIT
}

${ }^{13}$ Wawancara dengan Iksan mantri BRI 29 Desember 2018 pukul 09.00 WIT 
2) Menyiapkan Surat Pengakuan Hutang

3) Mengisi kuitansi pencairanKUR

2. Penandatanganan Perjanjian Pencairan KUR

Berkas atau kelengkapan pencairan disini adalah Surat Pengakuan Hutang, sebelum penandatanganan berkas pencairan kredit usaha rakyat, Customer Service harus memastikan bahwa dokumen-dokumen yang berhubungan dengan pencairan kredit usaharakyat telah ditandatangani oleh debitur sebagai bukti persetujuan debitur. Setelahitu, Customer Service meminta debitur untuk membaca dan memahami surat pengakuan hutang (SPH) dan menandatangani SPH tersebut selanjutnya diserahkan pada kepala unit untuk diperiksa. Untuk menjaga keamanan dan melaksanakan prinsip kehati-hatian maka Custumer Service mencocokkan tanda tangan dengan tanda tangan debitur pada waktu pendaftaran, kemudian menyerahkan semua berkas kepada Kepala Unit untuk di fiat bayar.

3. Fiat Bayar

Kepala Unit memeriksa berkas tentang kebenaran dan kelengkapan pengisian berkas kredit usaha rakyat untuk dicocokkan dengan syarat yang disebutkan dalam putusan kredit, setelah yakin maka kepala unit membubuhkan tandatangan sebagai persetujuan fiat bayar. Setelah selesai, kwitansi diserahkan pada teller dan berkas diserahkan pada customer service.

4. Pembayaran Pencairan KUR tanpa Jaminan

Pembayaran pencairan kredit usaha rakyat kepada debitur dilakukan oleh teller berdasarkan kwitansi yang diterima dari kepala unit dengan terlebih dahulu meneliti keabsahan kwitansi.

\section{B. Penyelesaian Kredit Macet Pada Bank BRI Merdeka Ternate}

Bank Rakyat Indonesia sebagai kreditor menyediakan uang kepada debitornya sebagai perjanjian kredit yang tata cara pelaksanaannya telah ditentukan terlebih dahulu mengenai hak-hak dan kewajiban dari masing-masing pihak, sehingga dari para pihak mengerti isi perjanjian yang ditandatangani tersebut, karena perjanjian tersebut akan mengikat hingga berakhirnya perjanjian sesuai Buku ke III Bab IV KUHPerdata Pasal 1381 tentang hapusnya perikatan-perikatan.

Mengenai kewajiban-kewajiban baik bank sebagai kreditor dan nasabah sebagai debitor diatur dalam Pasal 1759 KUHPerdata sampai dengan Pasal 1764 KUHPerdata, dimana yang menjadi kewajiban utama dari Bank Rakyat Indonesia meminjamkan atau menyerahkan sejumlah uang sesuai dengan putusan pimpinan, dan yang menjadi hak nya adalah Bank Rakyat Indonesia menerima kembali pembayaran sejumlah uang dan bunga yang telah ditetapkan Bank. ${ }^{14}$

Sedangkan yang menjadi hak dari Nasabah atau debitor adalah menerima pinjaman sejumlah uang dari Bank dan menggunakan uang tersebut sesuai dengan perjanjian dan kewajiban dari debitor adalah mengembalikan uang dan bunga sesuai dengan jumlah dan jangka waktu yang telah disepakati oleh kedua belah pihak.Selain itu upaya-upaya preventif yang dilakukan oleh pihak Bank Rakyat Indonesia selaku kreditor dalam memberikan pinjaman kredit adalah penilaian terhadap ar nasabah, kelayakan usahanya dan riwayat pinjaman kredit di Bank lainnya atau sejenisnya dan juga penilaian terhadap jaminan yang diagunkan tidak boleh melebihi dari Taksiran Harga Lelang Sekarang (THLS). Didalam penandatanganan Surat Perjanjian Hutang yang menggunakan perjanjian baku ini, Customer Service diharuskan untuk membacakan isi dari perjanjian kredit tersebut sehingga debitor mengerti akan hak-hak dan kewajibannya dalam perjanjian tersebut sehingga dapat meminimalisir dari terjadinya wan prestasi.

${ }^{14}$ Dokumen Bank BRI tentang kebijakan BANK pukul 16.00 WIT 
Untuk menjamin adanya kepastian hukum dari kedua belah pihak maka surat perjanjian hutang harus diwaarmeking dan dilegalisasi oleh pejabat yang berwenang yaitu Notaris, sehingga perjanjian tersebut mempunyai kekuatan hukum yang mengikat kedua belah pihak sehingga mengerti hak dan kewajibannya serta upaya-upaya hukum yang mungkin dapat dilakukan untuk melindungi hak-hak dari masing-masing pihak, hal ini juga dilakukan untuk menyelamatkan kredit yang dikhawatirkan macet serta mengetahui cara mengakhiri perjanjian kredit yang sesuai dengan aturan yang berlaku sesuai dengan KUHPerdata.

Setiap kredit yang dikeluarkan oleh Bank atau lembaga keuangan sejenisnya selalu memungkinkan untuk menjadi macet sehingga memberikan kerugian kepada Bank atau lembaga sejenisnya, dimana kredit macet adalah salah satu dari resiko yang harus dihadapi oleh Kreditor baik dari faktor kesalahan dari debitornya maupun faktor dari alam atau overmacht, dimana gejala alam atau faktor non tekhnis sering mempengaruhi setiap nasabah atau debitor untuk melakukan wan prestasi dalam hal ini adalah sengaja atau tidak sengaja melakukan wan prestasi terhadap pinjaman kreditnya yang telah jatuh tempo kepada Bank Rakyat Indonesia. Sama hal nya dengan pengertian wan prestasi dan macam-macam bentuk wanprestasi, didalam perjanjian kredit tersebut nasabah dianggap wan prestasi adalah ketika nasabah tidak membayar pinjman yang telah diperjanjikan, membayar tapi jumlahnya tidak sesuai dengan yang diperjanjikan, membayar tetapi waktunya tidak sesuai dengan yang diperjanjikan sehingga apa yang menjadi kewajibannya tidak dapat terpenuhi atau hanya terpenuhi sebagian yang membuat perjanjian tersebut dilanggar atau tidak ditaati yang membuat hilangnya hak-hak dari debitor.

Sesuai dengan hasil penelitian bahwa terdapat kurang lebih 10 kasus kredit macet di Bank Rakyat Indonesia Merdeka Ternate, yang terungkap adalah kredit macet kos-kosan. Yang dimana pihak Bank memberikan pinjaman sebesar 20.000,000 dengan jangka waktu 2 tahun. Setelah 6 bulan berjalan sang pemilik kos-kosan yang bertempat tinggal di tafure melarikan diri tanpa melunasi pinjaman di Bank, pemilik kosan lari ke kampungnya tanpa diketahui pihak Bank.

Ada juga masalah kredit macet seperti salah gunakan kredit, misalnya si nasabah datang ke Bank buat kredit sembako, tetapi bukan sembako yang di jalaninya tetapi bisnis lainnya, sehingga yang tadinya si nasabah itu mengambil kur sembako menjadi macet, karena tidak mampu membayar pinjaman di Bank. Dari pihak Bank sudah memberikan teguran berupa, Penagihan, Peringatan 1 dan 2 dan terakhir Askrindo.

Sebenarnya dari pihak Bank Rakyat Indonesia sebagai kreditor telah memberikan toleransi keterlambantan atau wan prestasi yaitu pembayaran pinjaman pokok dan bunga selama 7 hari asalkan tidak melebihi atau melewati akhir bulan, dan selama itu pula debitor masih dianggap sebagai debitor yang lancar, bahkan ketika debitor tidak membayar pinjaman selama 2 bulan maka status pinjamannya berubah menjadi daftar perhatian khusus dan secara tidak langsung mengganggu neraca pinjaman kredit Bank Rakyat Indonesia, dalam hal ini tata cara pinjaman kredit Bank Rakyat Indonesia adalah berlaku bulanan atau setiap bulan mengangsur pokok dan bunga dan pinjman berlaku musiman dimana dari awal berlaku pinjaman hingga akhir pinjaman debitor membayar sekali langsung lunas pokok dan bunga dalam jangka waktu yang telah disepakati.

Ada dua hal yang harus di perhatikan sebagai upaya untuk mencegah krtedit macet

1. Upaya Hukum.

Upaya hukum pencegahan kredit macet dilakukan persyaratan yang tidak kalah penting dan harus dipenuhi debitor untuk memperoleh kredit dari bank adalah mengenai domisili debitor, status pernikahan debitor, keabsahan atau legalitas dari agunannya dalam hal pemilik jaminan, Sistem Informasi Debitur, yang tidak kalah pentingnya adalah mengetahui 
karakteristik dari nasabah, apakah riwayat debitor tersebut baik atau tidak dalam kredit di Bank atau lembaga keuangan lainnya, dan yang tidak kalah penting dalam pemberian kredit adalah lahan pertanian yang digarap atau usaha yang dimiliki nasabah, dimana dalam perhitungannya RPC (RepaymentCapacity) harus mencukupi pembayaran jumlah pinjaman dari bank, sehingga kredit tersebut dapat di setujui dan diputus oleh kepala kantor Bank Rakyat Indonesia sebagai Kreditor.

2. Upaya Penyelamatan Kredit

Bank Rakyat Indonesia selaku kreditor akan selalu berusaha untuk menyelamtakan kredit yang bermasalah, dengan tujuan agar Bank tidak mengalami kerugian yang lebih besar lagi dan tidak akan mengganggu neraca keseimbangan kantor. Dalam hal ini apakah pihak Bank Rakyat Indonesia sudah mempersiapkan langkah-langkah hukum yang akan diambil apabila nantinya pihak debitor wan prestasi terhadap perjanjian kredit yang telah ditandatangani. Sehingga terdapat dua aspek penting yang dilakukan oleh Bank Rakyat Indonesia selaku kreditor yang memberikan kredit untuk mengambil tindakan hal tersebut, yang pertama adalah penyelamatan kredit bermasalah dan kedua adalah upaya untuk mengakhiri perjanjian kreditnya.

Upaya-upaya yang dilakukan Bank Rakyat Indonesia dalam rangka menyelamatkan pinjaman kredit, dilakukan dengan berbgaai cara, yaitu:

1) Pencantuman mengenai jumlah dari pinjaman kredit debitor.

2) Pencantuman klausula mengenai cara pembayaran kembali kredit.

1) Pencantuman klausula mengenai jumlah pembayaran kredit.

2) Pencantuman klausula mengenai pembayaran maju kredit.

3) Pencantuman Klausula menegenai denda dan IPTW kredit

4) Pencantuman klausula mengenai pengawasan dan pemeriksaan debitor saat dibutuhkan.

5) Pencantuman mengenai barang-barang jaminan.

6) Pencantuman klausula mengenai penyelesaian perselisihan atau domisili hukum kedua belah pihak.

Mengenai cara-cara pembayaran kredit berdasarkan aturan Bank Rakyat Indonesia adalah sebagai berikut :

1) Untuk pinjaman musiman debitor wajib membayar pokok dan bunga pinjaman satu kali dalam jangka waktu yang ditentukan, dan untuk pinjaman bulanan pembayaran pokok dan bunga pinjaman dilakukan setiap bulan dengan jangka waktu yang telah disepakati.

2) Pembayaran Pinjaman musiman dan pinjaman bulanan dibayarkan tepat sesuai tanggal realisasi kredit yang diberikan kelonggaran waktu 7 hari kerja asalkan tidak melewati akhir bulan.

3) Pembayaran tepat waktu yang dilakukan oleh debitor mendapatkan Insentif Pembayaran Tepat Waktu yang besarnya sesuai dengan jumlah pinjaman masingmasing debitor yang telah ditentukan Bank Rakyat Indonesia.

4) Debitor harus mempunyai rekening tanbungan di Bank Rakyat Indonesia sebagai tempat penampungan IPTW tersebut, dengan jumlah minimal tertentu untuk menjaga apabila sewaktu-waktu nasabah tidak mampu membayar pinjaman kreditnya

5) Pembayaran yang diterima Bank dari debitor akan diprioritaskan masuk ke dalam bunga pinjaman dulu dan kemudian pokok pinjamannya.

6) Debitor memberikan surat kuasa memotong gaji bulanan bagi debitor golongan berpenghasilan tetap yang dilakukan setiap awal bulan untuk membayar pinjaman kreditnya.

Dengan pencantuman Klausula kewajiban-kewajiban serta hak-hak yang akan diterima debitor, sebenarnya tindakan wan prestasi yang dilakukan oleh debitor sangat kecil dimana dengan memahami klausula-klausula yang telah menjadi kesepakatan tersebut pihak Bank 
Rakyat sangat memberikan kelonggaran bagi debitor untuk melakukan prestasi nya sehingga akan tercipta prinsip saling menguntungkan diantara kreditor dan debitor.Upaya Penyelamatan kredit yang dilakukan oleh pihak Bank didasarkan atas asas itikad baik dimana pihak debitor dan kreditor diharapkan sama-sama mempunyai itikad yang baik dalam penyelesaian kewajiban perjanjian kredit tersebut, pada prinsipnya Bank Rakyat Indonesia selalu memberi kemudahan dan keamanan serta kepastian hukum terhadap debitornya, sehingga selalu akan diupayakan tindakan-tindakan pengemanan dan penyelamatan kredit yang bermasalah atau macet sehingga didalam hubungannya antara Bank Rakyat Indonesia dengan masyarakat adalah hubungan simbiosis mutualisme atau hubungan yang saling membutuhkan, dimana Bank Rakyat Indonesia akan memperoleh keuntungan dari bunga yang didapat dan sebaliknya masyarakat akan memperoleh keuntungan dari adanya bantuan modal kredit untuk pertaniannya atau untuk pengembangan usahanya.

Upaya yang di ambil Bank Rakyat Indonesia untuk menjamin debitor membayar pinjaman kreditnya, dalam Pasal 4 surat perjanjian hutang menyebutkan"Untuk menjamin supaya pinjaman yang berhutang kepada bank dibayar dengan semestinya, baik pinjaman yang ditimbulkan karena pengakuan ini atau karena alasan lain, ataupun yang mungkin timbul padasuatu ketika termasuk bunga, denda, ongkos-ongkos dan biaya lainnya maka yang berhutang menyerahkan agunan yang berupa tanah atau tanah dan bangunan, tanaman dan hasil karya yang telah ada atau aka nada yang merupakan satu kesatuan dengan tanah dan yang merupakan milik pemegang hak tanah.

Apabila dipahami lebih jauh lagi oleh debitor, bahwasanya upaya penyelamatan kredit macet yang dilakukan oleh pihak Bank Rakyat Indonesia adalah tidak semata-mata untuk kepentingan kreditor saja akan tetapi penyelamatan kredit macet tersebut untuk melindungi nama baik dari debitor agar tidak menjadi daftar debitor yang dicekal oleh Bank Indonesia, dimana apabila pinjaman debitor sudah mengalami macet dan status nya berubah menjadi daftar hitam maka debitor tersebut tidak akan dapat mengambil pinjaman di Bank manapun, sehingga dengan itu Bank Rakyat Indonesia sangat hati-hati dalam menangani pinjaman yang macet

3. Upaya Mengakhiri Perjanjian.

Pemberian tolerasnsi yang diberikan Bank Sebagai kreditor terhadap debitor yang wanprestasi dan tidak ada itikad baik untuk menyelesaikan kewajibannya membayar pinjaman kredit kepada Bank bukan tanpa batas, dengan kata lain bilamana sampai batas waktu yang sudah ditentukan oleh Bank dan debitor tidak bisa melaksanakan kewajibannya, maka Bank Rakyat Indonesia selaku kreditor dapat melakukan upaya-upaya hukum untuk mengakhiri perjanjian kredit tersebut meskipun batas waktu perjanjian kredit belum berakhir. Didalam pasal 11 Syarat Umum perjanjian kredit menyebutkan "Dengan tidak memandang ketentuan tentang angsuran dan berakhirnya pinjaman yang diperjanjikan, Bank berhak menghentikan dan atau menagih seluruh hutang dengan segera, seketika, dan sekaligus lunas tanpa permintaan untuk diakhiri dan diberikan peringatan"

Dalam mengakhiri perjanjian kredit, tindakan yang dilakukan oleh Bank selaku kreditor adalah:

1) Melakukan penyitaan barang yang dijaminkan kepada Bank sesuai dengan ketentuan yang berlaku

2) Melakukan eksekusi dan pelelangan terhadap barang jaminan sesuai dengan surat kuasa yang diberikan debitor.

3) Melunasi seluruh sisa hutang yang dimiliki kepada kreditor dan membayar biaya-biaya yang dikeluarkan dan sisanya akan dikembalikan kepada debitor.

Tindakan hukum tersebut akan dilakukan oleh pihak Bank bilamana debitor melakukan wanprestasi, yaitu: 
1) Debitor tidak membayar pinjaman sesuai dengan jumlah yang telah ditetapkan dalam perjanjian kredit.

2) Debitor membayar pinjaman tapi tidak sesuai dengan waktu yang telah ditetapkan dalam perjanjian kredit.

3) Debitor melanggar ketentuan-ketentuan dan tidak melaksanakan kewajibannya sesuai dengan ketentuan yang telah disepakati bersaman.

4) Debitor memberikan keterangan-keterangan yang tidak sesuai dengan kenyataan yang sebenarnya.

Ketika debitor melakukan wan prestasi sebagaimana yang telah diuraikan diatas, maka upaya atau tindakan yang diambil oleh Bank Rakyat Indonesia sebagai pihak kreditor adalah dengan memanggil atau mendatangi debitor yang wan prestasi tersebut dan memberikan penjelasan mengenai kesalahan dan upaya hukum yang akan ditempuh pihak Bank apabila debitor tidak mempunyai itikad baik, memberikan surat peringatan kepada debitor untuk segera melaksanakan kewajibanya kepada kreditor dan apabila peringatan tersebut tidak di indah kan maka akan diberikan surat peringatan ke dua atau surat peringatan terakhir yang apabila tetap tidak ada tindakan dari debitor maka tindakan penyitaan dan pelelangan barang jaminan akan dilakukan oleh kreditor.

Namun begitu Bank rakyat Indonesia sebagai kreditor memberikan kesempatan kepada debitor untuk menyelesaikan kewajibannya sehingga kedua belah pihak sama-sama tidak saling merugikan, yaitu dengan menjual sendiri agunan yang dijaminkan kepada Bank, sehingga hasil penjualan tersebut dapat digunakan untuk membayar pinjaman kredit debitor, bahkan pihak Bank Rakyat Indonesia membantu debitor untuk mencarikan calon pembeli bagi yang berminat membeli jaminan milik debitor. Hal ini dimaksudkan adalah untuk penyelesaian kredit macet secara kekeluargaan dan hasil penjualan yang diterima oleh debitor lebih banyak apabila melakukan proses lelang, hal ini juga bertujuan untuk menghindari prosedur lelang yang banyak dan menyita banyak waktu.

\section{PENUTUP}

Berdasarkan data yang diperoleh di lapangan dan hasil pembahasan yang dilakukan makadapat diambil simpulan bahwa Pelaksanaan pemberian kredit usaha rakyat (KUR) dilakukan melalui beberapa tahap yaitu : tahap permohonan kredit, tahap peninjauan dan analisis kredit (tahap pemeriksaan), tahap pemberian putusan, serta tahap pencairan kredit/akad kredit. Terjadinya kredit macet bukan hanya disebabkan oleh pihak debitur tetapi keslahan dilakukan oleh pihak bank juga bisa menjadi salah satu penyebab terjadinya kredit macet, Misalnya salah dalam menganalisa kredit, dan tidak melakukan kontroling kepada nasabah secara bertahap.

\section{DAFTAR PUSTAKA}

Hukum Perbankan di Indonesia H. Dadang Husen Sobana. Pustaka Setia Bandung

H. Boedi Abdullah, Pengantar Hukum Perbankan cv pustaka setia 2016

Muhammad Djumahana,. Hukum "Perbankan di Indonesia" Penerbit PT CITRA ADITYA BAKTI BANDUNG 2012

Emmy Pangaribuan “Aspek-Aspekn Masalah Perkreditan”, Cetakan Pertama, Bandung 1987

Bank dan Lembaga Keuangan lainnyaJulias R Latumahisa, 2011, Jakarta Salemba Empat.

Kasmir. 2005. Dasar-dasar Perbankan.Jakarta: Raja Grafindo Persada.

Kasmir. 2005. Pemasaran Bank. Jakarta: Kencana.

Adrian Sutedi,SH.MH, 2010 Hak tanggungan CV Sinar Grafika 
Akuntansi PerbankanDr. Taswan, S.E., M.Si. Upp Stim Ykpn

Hermansyah. 2008. HukumPerbankan Nasional Indonesia. Jakarta:PrenadaMedia

Martono. 2004. Bank\& Lembaga Keuangan Lain. Edisi Ketiga. Ekonisia Yogyakarta.Rahmat Firdaus. 2004. Manajemen Perkreditan. Alfabeta, bandung.

Hassanuddin Rahman. 1998. Aspek-Aspek Hukum Pemberian Kredit Perbankan. PT. Citra Aditya Bakti, Bandung.

Endang Mintorowati. 1996.HukumPerjanjian. Surakarta:UNSPress

H.B.Soetopo.2002.MetodologiPenelitianKualitatif:DalamTeoriTerapannyadalamPenelitian. Surakarta:UNSPress

\section{PERATURAN}

Undang-undang Nomor 10 Tahun 1998 tentang Perbankan.

Undang-Undang Nomor 1 tahun 2004 tentang Perbendaharaan Negara.

Instruksi presiden Nomor 6 tanggal 8 juni 2007 tentang Kebijakan Percepatan Pengembangan Sektor Riil.

Peraturan presiden Nomor 5 tahun 2008 tentang Fokus Kerja Ekonomi.

Peraturan Menteri Keuangan Republik Indonesia Nomor 20/PMK. 05/2015 tentang Tata Cara Pelaksanaan Subsidi Bunga untuk Kredit Usaha Rakyat.

\section{SUMBER LAINNYA}

Https://serlania.bloqspot.co.id

https://www.scrid.bank.com

zriefmaronie.blogspot.com2013/04pengertian-sumber-hukum-perbankan

Wikipedia.org/wiki/kredit_usaha_rakyat

https://bank-rakyat-indonesia

kur.ekongo.id/landasan-hukum-kur 